\title{
Article/Artigo
}

\section{PCR detection of multiple human herpesvirus DNA in saliva from HIV-infected individuals in Teresina, State of Piauí, Brazil}

\author{
Detecção por PCR do DNA de vários herpesvírus humanos na saliva de indivíduos infectados \\ pelo HIV em Teresina, Estado do Piauí, Brasil
}

\author{
Kátia Silene Sousa Carvalho ${ }^{1}$, Ellida de Aguiar Silvestre ${ }^{1}$, Samira da Silva Maciel $^{1}$, Henrique Igor Gomes \\ Lira $^{1}$, Rodrigo Alves de Souza Galvão ${ }^{1}$, Maria José dos Santos Soares ${ }^{1}$, Carlos Henrique Nery Costa ${ }^{2}$, \\ Luiz Cosme Cotta Malaquias ${ }^{3}$ and Luiz Felipe Leomil Coelho ${ }^{3}$
}

\begin{abstract}
Introduction: Human herpesviruses are frequently associated with orofacial diseases in humans (HSV-1, EBV, CMV and HHV-8), some can also cause systemic disease (CMV and HHV-8). The transmission of these viruses occurs by contact with infected secretions, especially saliva. Human immunodeficiency virus infection is associated with an increased risk of HHVs and related diseases. Methods: This work aimed to detect HSV-1, EBV, CMV and HHV-8 DNA in saliva of HIV-infected patients from Teresina, northeast Brazil, by PCR and compare these findings with age and sex matched HIV-seronegative individuals. Results: No difference in prevalence was verified between HHV detection in the saliva of HIV-seropositive individuals and controls. The individual frequencies of these viruses in these two populations were different. HIV seropositivity correlated positively with the presence of CMV (OR: 18.2, $\mathrm{p}=0.00032$ ) and EBV (OR: 3.44, $\mathrm{p}=0.0081$ ). No association between CD4 counts and the prevalence of HHVs in the saliva was observed; however, a strong association was determined between seropositivity and the presence of multiple HHV DNAs in saliva (OR: 4.83, $\mathrm{p}=0.0028)$. Conclusions: These findings suggest the asymptomatic salivary shedding of HHVs is a common event between HIV-seropositive and seronegative individuals from Teresina, Piauí, Brazil, and, especially for HIV-seropositive patients, saliva is a risk factor for the acquisition/transmission of multiple HHVs.
\end{abstract}

Key-words: Human herpesvirus. Saliva. PCR. HIV seropositive.

\section{RESUMO}

Introdução: Alguns herpesvírus humanos são frequentemente associados a doenças orofaciais em humanos. A transmissão destes vírus ocorre através do contato com secreções contaminadas, especialmente a saliva. A infecção pelo vírus da imunodeficiência humana é considerada um fator de risco para a aquisição de HHVs e doenças correlatas. Métodos: Este trabalho teve como objetivo detectar por PCR o DNA de HSV-1, EBV, CMV e HHV-8 na saliva de pacientes infectados com HIV em Teresina, nordeste do Brasil, e comparar os dados obtidos com o grupo controle (indivíduos HIV negativos). Resultados: Não há diferença na prevalência de detecção de HHVs na saliva de indivíduos HIV soropositivos e soronegativos. No entanto, as frequências individuais de detecção dos diferentes HHVs são diferentes entre estas duas populações. A soropositividade para HIV apresentou correlação positiva com a presença de CMV (OR: 18,2, p = 0,00032) e EBV (OR: 3,44, p = 0,0081). Não foi verificada nenhuma associação entre a contagem de CD4 e prevalência de HHVs na saliva, no entanto existe uma forte associação entre a soropositividade e a detecção do DNA de vários HHVs na saliva (OR: 4,83, p=0,0028). Conclusões: Estes resultados sugerem que a transmissão salivar de HHVs é um evento comum entre os indivíduos HIV soropositivos e soronegativos de Teresina, Piauí, Brasil, e, especialmente para os pacientes soropositivos, a saliva é um fator de risco para a aquisição/transmissão de múltiplos HHVs.

Palavras-chaves: Herpesvirus humanos. Saliva. PCR. HIV soropositivo.

1. Parasitology and Microbiology Department, Federal University of Piauí, Teresina, PI, Brazil. 2. Laboratory of Leishmaniasis, Tropical Diseases Institute Natan Portella, Teresina, PI, Brazil. 3. Institute of Biomedical Science, Federal University of Alfenas, Alfenas, MG, Brazil.

Address to: Dr. Luiz Felipe Leomil Coelho. Lab Microbiologia Imunologia/Dept ${ }^{\circ}$ Ciências Biomédicas/ UNIFAL. Rua Gabriel Monteiro da Silva 714, Centro, 37130-000 Alfenas, MG, Brazil.

Phone: 5535 3299-1418; Fax : 5535 3299-1067

e-mail: luleomil@yahoo.com

Received in 05/12/2009

Accepted in 16/09/2010

\section{INTRODUCTION}

Human herpesviruses (HHVs) belong to the Herpesviridae family and are widely distributed viruses that cause benign and malignant disease in animals and humans. Human simplex virus 1 and 2 (HSV-1 and HSV-2), Varicella-zoster virus (VZV), Cytomegalovirus (CMV), Epstein-Barr virus (EBV), Human herpes virus 6 (HHV-6), Human herpes virus 7 (HHV-7) and Human herpes virus 8 (HHV-8) are known to cause infections in humans ${ }^{1}$. Among these, HSV-1, EBV, CMV and HHV-8 are frequently associated with orofacial diseases in humans. Additionally, EBV and HHV-8 are also implicated in systemic diseases ${ }^{2}$. The transmission of these viruses occurs by contact with infected secretions, especially saliva ${ }^{3-6}$. The majority of $\mathrm{HHV}$ infected individuals show no clinical symptoms, but can shed HHVs asymptomatically in saliva ${ }^{4,7,8}$.

Human immunodeficiency virus (HIV) is one of the most important pathogens of this century. Almost 33 million people are living with $\mathrm{HIV}^{9}$. It is clear that HHV-related diseases are a significant problem for HIV-seropositive patients. HIV oral manifestations induced by HHVs are frequently reported and include oral aphthous ulceration, AIDS-associated oral lymphoma, Kaposi sarcoma and oral hairy leukoplakia ${ }^{2}$.

Using PCR and real time PCR to detected HHV viral genomes in saliva, some research groups have been reported the prevalence of these viruses in the saliva of HIV-seropositive patients. The frequencies of these viruses are wide-ranging, varying from 62 to $90 \%$ for EBV; $57 \%$ for HHV-8; 19 to $72 \%$ for CMV and 5 to 16 for HSV-1 $1^{4,7,10-12}$. In these reports, the prevalence of HHVs was higher in HIV-seropositive patients than seronegative individuals. Thus, the molecular detection of HHVs in body fluids could be predictive of the development of HHV-related diseases and, consequently, would be of great benefit to the HIV-seropositive population. In Brazil, few 
studies exist that determine the frequencies of HHVs in HIV positive patients. The majority of studies report a high frequency of HHV-8 in HIV positive patients, but few studies also report high frequencies of CMV, EBV and HSV-1 and HSV-2 $2^{10,13,14}$. However, there is no available data regarding the serological or molecular frequency of HHVs in the State of Piauí (PI), northeast Brazil. Therefore, this study aimed to determine the prevalence of HSV-1, EBV, CMV and HHV-8 in the saliva of HIV-seropositive patients from Teresina, PI, by PCR and compare these findings with age and sex matched HIVseronegative individuals.

\section{METHODS}

\section{Study population and procedures}

Forty-four HIV-seropositive individuals were recruited from the Natan Portella Institute of Tropical Diseases (Instituto de Doenças Tropicais Natan Portella, IDTNP) in Teresina, PI. Forty age control subjects were recruited from the Federal University of Piauí campus including workers from the IDTNP. All samples were collected in 2008.

Immunochromatography assays for HIV-I and HIV-II (Inverness Medical) were performed on all controls to insure that they were HIV seronegative. All controls were in good general health. The inclusion criteria for control subjects were: they should be free of symptoms of acute illness (fever, headache, sore throat, body aches and diarrhea) and malignancies at the time of enrollment. The only inclusion criterion for HIV-seropositive patients was seropositivity, regardless of the presence or absence of symptoms. The exclusion criteria for both groups were pregnancy, use of immunosuppressant medications and administration of antiherpetic therapy one week before the study enrollment date. All patients and control subjects were submitted to oropharyngeal examinations in order to identify any oral alterations, such as mouth ulcers, gum bleeding, mouth pain, dry mouth, oral mucosal lesions and cervical lymphadenopathy. Unstimulated whole saliva $(3 \mathrm{ml})$ was collected in a sterile recipient ${ }^{15}$. The sample were divided into $1.5 \mathrm{ml}$ aliquots and frozen at $-20^{\circ} \mathrm{C}$ until use. Determination of CD 4 count was performed by flow cytometry.

DNA extraction from saliva, primers and polymerase chain reaction

DNA from $1.5 \mathrm{ml}$ of each saliva specimen was centrifuged and the DNA was isolated from the cell pellet using the phenol-chloroform method described by Anzai-Kanto et a ${ }^{16}$. Two microliters of DNA were used in each PCR reaction. The integrity of the extracted DNA and the exclusion of PCR inhibitors in samples were confirmed by amplifying the human $\beta$-globin gene ${ }^{17}$. The primers for CMV genome detection (HSVF 5' - GACTTTGCCAGCCTSTACCC-3' and CMVR 5'- CTCTCCTCCGAATCCCCC-3') were based on the DNA polymerase gene of CMV (GenBank accession number AB329634.1) and amplified 499 base pairs PCR products. The amplification mixture for CMV contained $10 \mathrm{pM}$ of each primer, $0.1 \mathrm{mM}$ of each dNTP, $0.1 \mathrm{U}$ Taq polymerase, Taq buffer, $1,5 \mathrm{mM}$ $\mathrm{MgCl} 2$ concentration, $2 \mu \mathrm{l}$ template and distilled water in a final volume of $20 \mu \mathrm{l}$. PCR amplification was performed at $94^{\circ} \mathrm{C}$ for $5 \mathrm{~min}$ (1 cycle); $94^{\circ} \mathrm{C}$ for $1 \mathrm{~min}, 58^{\circ} \mathrm{C}$ for $1 \mathrm{~min}$ and $72^{\circ} \mathrm{C}$ for $1 \mathrm{~min}$ ( 35 cycles); and $72^{\circ} \mathrm{C}$ for $10 \mathrm{~min}$ ( 1 cycle). PCR for the detection of HSV-1, EBV and HHV-8 was performed using the oligonucleotide primers and conditions described previously ${ }^{18-20}$ (Table 1). The specificities of the primer pairs were validated by DNA sequencing of the PCR products. Genomic DNAs extracted from clinical
TABLE 1 - Genome targets and references for HHV genomes and b-globin detected by PCR.

\begin{tabular}{lcc}
\hline & Genome targets & Reference \\
\hline HSV-1 & Thymidine Kinase & {$[18]$} \\
CMV & DNA polymerase & This study \\
EBV & EBNA-1 & {$[19]$} \\
HHV-8 & orf64-orf65 & {$[20]$} \\
$\beta$-globin & b-globin gene & {$[17]$}
\end{tabular}

HSV: human herpesvirus type 1, CMV: cytomegalovirus, EBV: Epstein-Barr virus, EBNA-1: Epstein-Barr virus nuclear antigen 1

samples were used as positive control standards for HSV-1, CMV and EBV previously confirmed by $\mathrm{PCR}^{10}$. The genomic DNA extracted from BCBL-1 cells was used as positive control standard for HHV-8. The amplified PCR products were run on $2 \%$ agarose gel stained with ethidium bromide and visualized under a UV light transilluminator. The PCR was performed with strict adherence to the universal quality control guidelines. All reactions performed involved sample preparation, reaction mix preparation, amplification and electrophoresis in separate rooms to avoid cross-contamination.

\section{Statistical analysis}

Odds ratios (and 95\% confidence intervals) were based on $2 \times 2$ contingency tables and were calculated to assess the association between the presence of a virus and demographics or associated factors (CD4 counts). The significance of measurement was determined by the Chi square $\left(\chi^{2}\right)$ and Fisher exact tests.

\section{Ethical}

The present study was approved by the Committee of Ethics in Research at the Federal University of Piauí (UFPI) (protocol number 0240.0.045.000-07) and all patients provided written informed consent as part of the study protocol.

\section{RESULTS}

The study was conducted in 2008 and according to analysis of the results, the $44 \mathrm{HIV}$-seropositive individuals were demographically similar to the 40 controls. The demographic analysis indicated that the average age of HIV-seropositive individuals was 35.89 years-old and 33.92 years-old for control subjects. The majority of individuals in both groups were men whose marital status was single (Table 2).

TABLE 2 - Demographic characteristics of the study population.

\begin{tabular}{lccc}
\hline Serostatus & Sex & Marital status & Age range (mean \pm SD) \\
\hline HIV seropositive & $32 \mathrm{M} ; 12 \mathrm{~W}$ & $31 \mathrm{~S} ; 13 \mathrm{Ma}$ & $25-59(35.89 \pm 7.98)$ \\
HIV seronegative & 29M; 11W & $23 \mathrm{~S} ; 17 \mathrm{Ma}$ & $21-51(33.92 \pm 9.25)$ \\
\hline
\end{tabular}

M: men, W: women, S:single, Ma: married, SD: standard derivation.

None of the HIV-seropositive patients presented signs or symptoms of oral lesions caused by any HHVs or symptomatic Kaposi sarcoma. Twenty HIV-seropositive patients presented secondary diseases: visceral leishmaniosis $(7 / 20)$, tuberculosis $(5 / 20)$, fungal meningitis $(3 / 20)$, oral candidiasis $(3 / 20)$, Pneumocystis carinii pneumonia $(2 / 20)$ and genital herpes $(1 / 20)$. Among the HIV-seronegative individuals, only five $(5 / 40)$ presented oral herpes.

After PCR assays, 75\% of HIV-seropositive patients (33/44) had detectable salivary HHV DNAs. Among the $40 \mathrm{HIV}$-negative subjects, salivary HHVs were detected in 31 (77.5\%) of the 40 samples tested. In the HIV-seropositive group, the most prevalent 
virus was HSV-1 (51.1\%), followed by EBV (48.8\%), CMV (31.1\%) and HHV-8 (26.6\%). In contrast, in the seronegative group, the most prevalent virus was HHV-8 and HSV-1 (40\% each), followed by EBV (22.5\%) and CMV (2.5\%) (Table 3). Statistical analysis indicated no significant difference in the presence of HSV-1 and HHV-8 in HIV-positive patients compared to controls. Statistical analysis showed a strong correlation between the presence of CMV (OR: 18.2, p= 0.00032) and EBV (OR: 3.44, p= 0.0081) and HIV seropositivity. The prevalence of HHVs analyzed in the saliva of HIV-infected patients with CD4 counts less than 200 cells $/ \mathrm{mm}^{3}$ presented no statistical difference compared to those with CD4 counts greater than 200 cells $/ \mathrm{mm}^{3}$ (data not showed).

TABLE 3 - Prevalence of human herpesvirus in saliva of HIV seropositive patients from northeast Brazil.

\begin{tabular}{|c|c|c|c|c|c|c|}
\hline & \multicolumn{4}{|c|}{ Serostatus } & \multirow[b]{3}{*}{ OR $(95 \% \mathrm{CI})$} & \multirow[b]{3}{*}{$\mathrm{p}$ value } \\
\hline & \multicolumn{2}{|c|}{ HIV seropositive } & \multicolumn{2}{|c|}{ HIV seronegative } & & \\
\hline & $\mathrm{n}$ & $\%$ & $\mathrm{n}$ & $\%$ & & \\
\hline HHV-8 & 12 & 26.6 & 16 & 40.0 & 0.56 & 0.15 \\
\hline $\mathrm{CMV}$ & 14 & 31.1 & 1 & 2.5 & 18.2 & 0.00032 \\
\hline HSV-1 & 23 & 51.1 & 16 & 40.0 & 1.36 & 0.31 \\
\hline EBV & 22 & 48.8 & 9 & 22.5 & 3.44 & 0.0081 \\
\hline None & 11 & 25.0 & 10 & 25.0 & 1 & 0.59 \\
\hline
\end{tabular}

HSV-1: human herpesvirus type 1, CMV: cytomegalovirus, EBV: Epstein Barr virus, HHV-8: human herpesvirus type 8, OR: odds ratio, CI: confidence interval.

Interestingly, a strong association was verified between seropositivity and the presence of multiple HHV DNAs in saliva (OR 4.83, $\mathrm{p}=0.0028$ ). Saliva of HIV-positive patients showed a high frequency of coinfection by three different HHVs (OR 17.1429, $\mathrm{p}=0.0008$ ) (Table 4). Viruses most likely to be simultaneously present in the saliva of HIV-seropositive patients were HSV-1 and EBV, CMV, HSV-1 and EBV, HHV-8, HSV-1 and EBV, and HSV-1, CMV and HHV-8 (data not shown).

TABLE 4 - Relation between HIV serostatus and presence of multiple HHVs in saliva.

\begin{tabular}{lccccccc}
\hline & \multicolumn{2}{c}{$\begin{array}{c}\text { HHV PCR } \\
\text { positive }\end{array}$} & & \multicolumn{2}{c}{ Number of patients with presence of coinfection } \\
\cline { 2 - 3 } HIV & $\mathrm{n}$ & $\%$ & & one HHV & two HHVs & three HHVs & four HHVs \\
\hline Seropositive & 33 & 75.0 & & 10 & 9 & $12^{*}$ & 2 \\
Seronegative & 31 & 77.5 & & $21^{* *}$ & 9 & 1 & 0 \\
\hline
\end{tabular}

HIV: human immunodeficiency virus, HHV: human herpesvirus, PCR: polymerase chain reaction.

${ }^{*}$ OR $17.1429, \mathrm{p}=0.0008 .{ }^{* *}$ OR $0.207, \mathrm{p}=0.0028$

\section{DISCUSSION}

Saliva, blood, cerebrospinal fluid, tissue and skin lesion samples have all been used for HHV diagnosis by $\mathrm{PCR}^{21-26}$. Since HHVs have different susceptibilities to antiviral drugs, rapid and precise diagnosis of the HHVs involved in a specific pathology is very important.

As expected, after PCR assays for HSV-1, EBV, CMV and HHV-8, a high prevalence of HHVs in saliva of HIV seropositive and seronegative individuals was observed: $75 \%$ for HIV seropositive and $77.5 \%$ for seronegative. The present data is consistent with other studies that showed evidence of infection with HHVs in the majority of the world's populations ${ }^{27-30}$.
In our cohort, $70.4 \%$ of HIV-seropositive patients were taking highly active antiretroviral therapy (HAART) and this therapy could alter the frequency of oral lesions caused by these viral agents. Besides the high frequencies of HHVs in saliva from HIV-infected patients, none of these patients presented oral lesions due to HHV activity. This could be explained by the fact that HHVs are frequently shed asymptomatically in the saliva of HIV-infected patients under HAART ${ }^{4,8,31,32}$.

The frequency of HHVs in these patients indicates that asymptomatic HHV shedding in saliva is a common event even in the presence of HAART. One of the Brazilian public health priorities is to make HIV medications available free of charge to all HIV-seropositive patients ${ }^{33}$. The consequences of universal access to HAART include a reduction in the number of deaths by AIDS and a reduction of the incidence of opportunistic diseases ${ }^{34}$. Therefore, the present data, in conjunction with other reports, corroborate the hypothesis that HAART has little effect on HHV shedding in saliva, because all HHVs tested in this study were frequently detected in HIV-infected patients. However, the statistical analysis only showed a risk for CMV and EBV shedding in the saliva of HIV-seropositive patients. These data are consistent with other studies that showed high CMV and EBV salivary shedding among more immunosuppressed patients in comparison with HIV-seronegative individuals $s^{4,7,10}$. Even in patients submitted to HAART, EBV and CMV shedding appears to persist at a higher frequency compared with HIV-uninfected controls ${ }^{8,12}$. This finding is in agreement with other studies in Brazil that also showed a high prevalence of CMV and EBV in HIV-seropositive patients ${ }^{10 ; 35}$.

Besides the differential prevalence, the most relevant data from this study is the high prevalence of HHV coinfection in HIV-seropositive patients. The majority of the HIV-seropositive group presented at least two detectable HHVs in the saliva. A 17fold increase in the odds of triple infection detection in saliva was demonstrated. This data is consistent with other studies that reported a high prevalence of multiple HHVs in the saliva of HIV-seropositive patients and suggests that salivary shedding of all HHVs are a common event among patients receiving HAART treatment ${ }^{4,10,35}$. The presence of HHV coinfection in HIV-positive individuals could be due to a lack of immunosurveillance by virus-specific $\mathrm{CD}^{+}$cytotoxic T lymphocytes and virus specific $\mathrm{CD} 4+\mathrm{T}$ cells ${ }^{36-37}$.

In summary, the observations reported herein suggest that the presence of HHVs in saliva is a frequent event in HIV-infected individuals from northeastern Brazil and seropositivity increases the risk of multiple infections in these patients, even in the presence of HAART therapy. This study represents the first report of the prevalence of multiple salivary HHVs in HIV-seropositive patients and HIVseronegative individuals from Teresina, PI, northeast Brazil.

\section{ACKNOWLEDGMENTS}

The authors would like to thank Dr. Claudio S. Pannuti and Dra. Liliane J. Grando for providing PCR controls.

\section{CONFLICT OF INTEREST}

The authors declare that there is no conflict of interest. 


\section{FINANCIAL SUPPORT}

This work was supported by the Fundação de Amparo à Pesquisa do Estado do Piauí, Conselho Nacional de Desenvolvimento Científico e Tecnológico and Ministério da Saúde (Grant number PROJ_036_9339376).

\section{REFERENCES}

1. Schleiss MR. Persistent and recurring viral infections: the human herpesviruses. Curr Probl Pediatr Adolesc Health Care 2009; 39:7-23.

2. Leão JC, Ribeiro CM, Carvalho AA, Frezzini C, Porter S. Oral complications of HIV disease. Clinics (Sao Paulo) 2009; 64:459-470.

3. Al-Otaibi LM, Al-Sulaiman MH, Teo CG, Porter SR. Extensive oral shedding of human herpesvirus 8 in a renal allograft recipient. Oral Microbiol Immunol 2009; 24:109-115

4. Miller CS, Berger JR, Mootoor Y, Avdiushko SA, Zhu H, Kryscio RJ. High prevalence of multiple human herpesviruses in saliva from human immunodeficiency virus-infected persons in the era of highly active antiretroviral therapy. J Clin Microbiol 2006; 44:2409-2415.

5. Saygun I, Kubar A, Ozdemir A, Slots J. Periodontitis lesions are a source of salivary cytomegalovirus and Epstein-Barr virus. J Periodontal Res 2005; 40:187-191.

6. Kaufman HE, Azcuy AM, Varnell ED, Sloop GD, Thompson HW, et al. HSV-1 DNA in tears and saliva of normal adults. Invest Ophthalmol Vis Sci $2005 ; 46: 241-247$

7. Griffin E, Krantz E, Selke S, Huang ML, Wald A. Oral mucosal reactivation rates of herpesviruses among HIV-1 seropositive persons. J Med Virol 2008; 80:1153-1159.

8. Lucht E, Brytting M, Bjerregaard L, Julander I, Linde A. Shedding of cytomegalovirus and herpesviruses 6,7 , and 8 in saliva of human immunodeficiency virus type 1-infected patients and healthy controls. Clin Infect Dis 1998; 27:137141.

9. World population highlights: key findings from PRB's 2007 world population data sheet. Population Reference Bureau 2007; Available on http://www.prb. org/pdf07/62.3highlights.pdf

10. Grande SR, Imbronito AV, Okuda OS, Lotufo RF, Magalhaes MH, Nunes FD. Herpes viruses in periodontal compromised sites: comparison between HIVpositive and -negative patients. J Clin Periodontol 2008; 35:838-845.

11. Widmer IC, Erb P, Grob H, Itin P, Baumann M, Stalder A, et al. Human herpesvirus 8 oral shedding in HIV-infected men with and without Kaposi sarcoma. J Acquir Immune Defic Syndr 2006; 42:420-425.

12. Ling PD, Lednicky JA, Keitel WA, Poston DG, White ZS, Peng R, et al. The dynamics of herpesvirus and polyomavirus reactivation and shedding in healthy adults: a 14-month longitudinal study. J Infect Dis 2003; 187:1571-1580.

13. Batista MD, Ferreira S, Sauer MM, Tomiyama H, Giret MT, Pannuti CS, et al. High human herpesvirus $8(\mathrm{HHV}-8)$ prevalence, clinical correlates and high incidence among recently HIV-1-infected subjects in Sao Paulo, Brazil. PLoS One 2009; 4:e5613.

14. Magri MC, Carbone PH, de los Santos-Fortuna E, Caterino-de-Araujo A. A comparative study of the frequency of antibody and titers against human herpesvirus 8 latent and lytic antigens in "at-risk" individuals and among patients with Kaposi’s sarcoma. J Med Virol 2009; 81:1292-1297.

15. Navazesh M. Methods for collecting saliva. Ann N Y Acad Sci 1993; 694:72-77.

16. Anzai-Kanto E, Hirata MH, Hirata RD, Nunes FD, Melani RF, Oliveira RN. DNA extraction from human saliva deposited on skin and its use in forensic identification procedures. Braz Oral Res 2005; 19:216-222.

17. Cho NH, Kang S, Hong S, Jeong GB, Choi IW, Choi HJ, et al. Multinucleation of koilocytes is in fact multilobation and is related to aberration of the G2 checkpoint. J Clin Pathol 2005; 58:576-582.
18. Nogueira ML, Siqueira RC, Freitas N, Amorim JB, Bonjardim CA, Ferreira PC, et al Detection of herpesvirus DNA by the polymerase chain reaction (PCR) in vitreous samples from patients with necrotising retinitis. J Clin Pathol 2001; 54:103-106.

19. Baldanti F, Grossi P, Furione M, Simoncini L, Sarasini A, Comoli P, et al. High levels of Epstein-Barr virus DNA in blood of solid-organ transplant recipients and their value in predicting posttransplant lymphoproliferative disorders. J Clin Microbiol 2000; 38:613-619.

20. Spira TJ, Lam L, Dollard SC, Meng YX, Pau CP, Black JB, et al. Comparison of serologic assays and PCR for diagnosis of human herpesvirus 8 infection. J Clin Microbiol 2000; 38:2174-2180.

21. Engelmann I, Petzold DR, Kosinska A, Hepkema BG, Schulz TF, Heim A. Rapid quantitative PCR assays for the simultaneous detection of herpes simplex virus, varicella zoster virus, cytomegalovirus, Epstein-Barr virus, and human herpesvirus 6 DNA in blood and other clinical specimens. J Med Virol 2008; 80:467-477.

22. Mbulaiteye SM, Pfeiffer RM, Engels EA, Marshall V, Bakaki PM, Owor AM, et al. Detection of kaposi sarcoma-associated herpesvirus DNA in saliva and buffy-coat samples from children with sickle cell disease in Uganda.J Infect Dis 2004; 190:1382-1386.

23. Minjolle S, Arvieux C, Gautier AL, Jusselin I, Thomas R, Michelet C, et al Detection of herpesvirus genomes by polymerase chain reaction in cerebrospinal fluid and clinical findings. J Clin Virol 2002; S59-70.

24. DeBiasi RL, Kleinschmidt-DeMasters BK, Weinberg A, Tyler KL. Use of PCR for the diagnosis of herpesvirus infections of the central nervous system. J Clin Virol 2002; S5-11.

25. Quereda C, Corral I, Laguna F, Valencia ME, Tenorio A, Echeverria JE, et al. Diagnostic utility of a multiplex herpesvirus PCR assay performed with cerebrospinal fluid from human immunodeficiency virus-infected patients with neurological disorders. J Clin Microbiol 2000; 38:3061-3067.

26. Malkin JE. Epidemiology of genital herpes simplex virus infection in developed countries. Herpes 2004; 2A-23A.

27. Schillinger JA, Xu F, Sternberg MR, Armstrong GL, Lee FK, Nahmias AJ, et al National seroprevalence and trends in herpes simplex virus type 1 in the United States, 1976-1994. Sex Transm Dis 2004; 12:753-760.

28. Smith JS, Robinson NJ. Age-specific prevalence of infection with herpes simplex virus types 2 and 1: a global review. J Infect Dis. 2002; 1:S3-28.

29. Kangro HO, Osman HK, Lau YL, Heath RB, Yeung CY, Ng MH. Seroprevalence of antibodies to human herpesviruses in England and Hong Kong. J Med Virol 1994; 43:91-96.

30. Triantos D, Horefti E, Paximadi E, Kyriakopoulou Z, Karakassiliotis G Papanastasiou K, et al. Presence of human herpes virus- 8 in saliva and non-lesional oral mucosa in HIV-infected and oncologic immunocompromised patients. Oral Microbiol Immunol 2004; 19:201-204.

31. Lampinen TM, Critchlow CW, Kuypers JM, Hurt CS, Nelson PJ, Hawes SE, et al. Association of antiretroviral therapy with detection of HIV-1 RNA and DNA in the anorectal mucosa of homosexual men. Aids 2000; 4:F69-75.

32. Ford N, Wilson D, Costa Chaves G, Lotrowska M, Kijtiwatchakul K. Sustaining access to antiretroviral therapy in the less-developed world: lessons from Brazil and Thailand. Aids 2007; S21-29.

33. Panos G, Samonis G, Alexiou VG, Kavarnou GA, Charatsis G, Falagas ME. Mortality and morbidity of HIV infected patients receiving HAART: a cohort study. Curr HIV Res 2008; 6:257-260.

34. Grando LJ, Machado DC, Spitzer S, Nachman S, Ferguson F, Berentsen B, Yurgel LS. Viral coinfection in the oral cavity of HIV-infected children: relation among HIV viral load, CD4+ T lymphocyte count and detection of EBV, CMV and HSV. Braz Oral Res 2005; 19:228-234.

35. Jacobson MA, Ditmer DP, Sinclair E, Martin JN, Deeks SG, Hunt P, et al. Human herpesvirus replication and abnormal CD8 $+\mathrm{T}$ cell activation and low CD4+ T cell counts in antiretroviral-suppressed HIV-infected patients. PloS one. 2009; 4:e5277.

36. Khanna R, Burrows SR. Role of cytotoxic T lymphocytes in Epstein-Barr virusassociated diseases. Annu Rev Microbiol 2000; 54:19-48.

37. Landais E, Saulquin X, Houssaint E. The human $\mathrm{T}$ cell immune response to Epstein-Barr virus. Int J Dev Biol 2005; 49:285-292. 